\title{
Kesepakatan Menunda Kehamilan Bagi Pasangan Muda Perspektif Hukum Islam: Upaya Menekan Pernikahan Dini di Masa Pandemi
}

\author{
Anton Jamal ${ }^{1}$, M. Ikhwan ${ }^{2 *}$ \\ STAIN Teungku Dirundeng Meulaboh \\ Jln. Alue Peunyareng Ujong Tanoh Darat Kec. Meureubo Kab. Aceh Barat \\ Email: ${ }^{1} a n t o n . j a m a l @ s t a i n d i r u n d e n g . a c . i d,{ }^{2 *}$.ikhwan@staindirundeng.ac.id,
}

\begin{tabular}{llll} 
Submit & $:$ 15 Juli 2021 & Diterima & $:$ 17 Nopember 2021 \\
Revisi & $: 16$ Oktober 2021 & Terbit & $: 1$ Desember 2021 \\
\hline
\end{tabular}

\begin{abstract}
This research is an attempt to look deeper into why delaying early marriage is appropriate during the Covid-19 pandemic based on the view of Islamic law and the human rights approach. The phenomenon of early marriage during the pandemic had appeared and even jumped based on the data collected. This phenomenon encourages conditions of vulnerability (figh; mudharat) which will have an impact on the emergence of new problems and even conflicts for young people, especially if they already have children, given the pandemic conditions that often threaten the household economy. This study departs from the question of why Islamic law and human rights must play a role in reducing the number of early marriages during the pandemic based on the assumption of household vulnerability? How is the phenomenon of early marriage during the pandemic seen from the point of view of human rights and maqasid? This research is analytical descriptive with qualitative methods, and data collection is carried out by literature study on secondary materials to observe the phenomenon of early post-marriage during the pandemic. The results show that the function of Islamic law and human rights can be an important instrument to suppress the surge in early marriage, which will save young households from the vulnerability of household conflicts based on observations made during the covid pandemic.
\end{abstract}

Keywords: Delaying pregnancy; Early-age marriage; Islamic law; Covid-19 pandemic.

Abstrak: Penelitian ini adalah upaya untuk melihat lebih dalam mengapa penundaan pernikahan dini layak dilakukan di masa pandemi Covid-19 berdasar pandangan Hukum Islam dan pendekatan hak asasi manusia. Fenomena pernikahan dini di masa pandemi sempat muncul bahkan melonjak berdasar data yang dihimpun. Fenomena ini mendorong kondisi kerentanan (fikih; mudharat) yang akan berdampak pada munculnya problem baru bahkan konflik bagi kalangan muda, apalagi jika sudah memiliki anak, mengingat kondisi pandemi yang kerap mengancam ekonomi rumah tangga. Studi ini berangkat dari pertanyaan mengapa hukum Islam dan hak asasi manusia harus berperan menekan angka pernikahan dini di masa pandemi berdasar asumsi kerentanan rumah tangga? Bagaimana fenomena pernikahan dini di masa pandemi dilihat dari sudut hak asasi manusia dan maqasid? Penelitian ini bersifat deskriptif analitis dengan metode kualitatif, dan pengumpulan data dilakukan dengan studi pustaka pada bahan-bahan sekunder untuk mengamati fenomena pasca-pernikahan dini di masa pandemi. Hasil penelitian menunjukkan jika fungsi hukum Islam dan hak asasi manusia dapat menjadi instrumen penting menekan lonjakan pernikahan dini, yang 
akan menyelamatkan rumah tangga usia muda dari kerentanan konflik rumah tangga berdasar pengamatan yang dilakukan selama pandemi covid berlangsung.

Kata kunci: Menunda kehamilan; Pernikahan dini; Hukum Islam; Pandemi Covid-19.

\section{Pendahuluan}

Dalam UU Perkawinan No. 1 tahun 1974 terdapat ketentuan yang mengatur tentang batas minimal umur pasangan yang akan melakukan perkawinan, yakni calon suami sekurang-kurangnya berumur 19 tahun dan calon isteri sekurang-kurangnya berumur 16 tahun. ${ }^{1}$ Ketentuan dalam UU Perkawinan ini diperkuat oleh Kompilasi Hukum Islam (KHI) pasal 15 ayat (1). ${ }^{2}$ Lebih lanjut telah dilakukan perubahan atas UU Perkawinan No 11974 dengan dikeluarkannya UU No. 16 tahun 2019 yang mengatur tentang penambahan usia minimal kawin sekaligus menyamakan usia perempuan dan laki-laki menjadi sama-sama 19 tahun. $^{3}$

Ketentuan-ketentuan ini terlihat sebagai sebuah terobosan baru dalam perkembangan hukum Islam di Indonesia, mengingat dalam kitab-kitab fiqh klasik yang menjadi rujukan para hakim di Indonesia, terutama dalam mazhab syafi'i tidak ditemukan penjelasan khusus yang mengatur tentang batasan umur tersebut. Kitab-kitab fiqh hanya menyebutkan baligh sebagai ukuran seseorang dianggap dewasa, sehingga dianggap layak untuk memikul beban hukum (taklif). Namun terkait pernikahan, tidak ketentuan yang menjelaskan bahwa pasangan yang menikah harus baligh. Namun secara umum penjelasan dalam kitab-kitab fiqh klasik itu mengisyaratkan bahwa anjuran menikah ditujukan kepada pasangan yang telah dewasa, terutama bagi laki-laki yang sudah memiliki keinginan kuat untuk memiliki pasangan hidup, bersedia bertanggung jawab serta mampu menafkahi diri sendiri dan isterinya, dan tidak khawatir akan terjerumus ke dalam perbuatan keji, seandainya ia belum menikah. Isyarat dewasa ini tidak diarahkan kepada perempuan. ${ }^{4}$

Bahkan dari adanya ketentuan tentang wali mujbir, yaitu wali dari pihak perempuan yang memiliki kewenangan untuk memaksa, dalam arti boleh menikahkan anak perempuannya dengan laki-lakiyang melamarnya tanpa meminta persetujuan dari anak perempuan tersebut, dapat dipahami bahwa seorang wali mujbir boleh menikahkan perempuan yang masih anak-anak dengan laki-laki yang dikehendakinya. ${ }^{5}$ Adapun saat ini batasan usia dewasa telah mengalami pergeseran, terutama jika dilihat dari aspek fisik dan psikis seseorang. Netmums-situs internet untuk kaum ibu di Inggrismenyatakan anak mendapat tekanan yang kuat agar berkembang lebih cepat. "Irama kehidupan modern terlalu cepat mengambil masa kanak-kanak yang amat berharga," tutur Siobhan Freegard, pendiri Netmums. "Anak tidak ingin lagi dilihat sebagai anak-anak walaupun sebagai orangtua, kita tahu mereka masih anak-anak."

1 Undang-Undang Perkawinan No. 1 Tahun 1974 Pasal 7 Ayat (1).

2 Direktorat Pembinaan Badan Peradilan Agama Islam Direktorat Jenderal Pembinaan Kelembagaan Agama Islam Departemen Agama R.I, Kompilasi Hukum Islam, 2001, 19.

3 “Undang-Undang No. 16 Tahun 2019" (n.d.). Pasal 7.

4 Musthafa Dib al-Bugha, Muthafa al-Khin, 'Ali Syurbaji, Al-Fiqh Al-Manhaji ‘Ala Madzhab Al-Imam Al-Syafi'I (Damaskus: Dar alMusthafa, 2016), 333.

5 Musthafa Dib al-Bugha, Muthafa al-Khin, 370.

6 BBC News, “Anak Sekarang Terlalu Cepat Dewasa," BBC NEWS Indonesia, 2013, https://www.bbc.com/indonesia/ majalah/2013/03/130306_pendidikan_anak. 
Meningkatnya kesadaran masyarakat, dan ketersediaan makanan yangbergizi serta mengandung protein tinggi, di samping tersedianya berbagai media yang memudahkan anak-anak dan para remaja dalam mengakses konten-konten dewasa, membuat mereka lebih cepat tumbuh dewasa dibanding generasi para orang tua mereka dahulu. Dalam buku The New Puberty, Dari kumpulan berbagai hasil penelitian tentang pubertas selama 200 tahun belakangan sebagaimana disebutkan dalam buku The New Puberty, ditemukan bahwa pada awalnya penyebab anak puber di usia lebih muda, disebabkan adanya perbaikan nutrisi secara global. ${ }^{7}$

Namun kedewasaan fisik dan psikis itu seringkali tidak berbanding sejalan dengan kemampuan menafkahi diri sendiri, dan tumbuhnya rasa tanggung jawab terhadap keluarga. Tingginya angka pengangguran, dan sulitnya mencari lapangan pekerjaan, terutama saat pandemi Covid-19. Menteri keuangan Sri Mulyani menyatakan bahwa Covid-19 tidak hanya mengancam kesehatan manusia, tetapi virus ini juga mengganggu perekonomian di berbagai negara, salah satunya di Indonesia, pada bagian pariwisata contohnya, sebagai salah satu wadah yang memberikan lapangan perkerjaan bagi masyarakat, kehadiran Covid-19 membuat banyak di antara mereka yang kehilangan pekerjaan. Tidak hanya pariwisata, bahkan banyak juga pekerja-pekerja pabrik yang terkena imbasnya, karena mengalami kelumpuhan sementara. ${ }^{8}$

Hal ini akan menambah problematika bagi pasangan yang akan menikah, terutama pasangan yang akan melakukan pernikahan dini. Sementara kecenderungan ke arah maraknya pernikahan dini ini semakin besar. Dalam data Direktorat Jenderal Badan Peradilan Agama, tercatat 34 ribu permohonan dispensasi kawin sepanjang Januari-Juni 2020. Dari jumlah tersebut, sebagian besar bahkan mencapai $97 \%$ dikabulkan, dan 60\% yang mengajukan permohonan itu adalah anak-anak di bawah 18 tahun. Jumlah tersebut jauh lebih tinggi dibandingkan tahun sebelumnya yang berjumlah 23.700. Permohonan dispensasi dilakukan karena salah satu atau kedua calon mempelai belum memasuki usia kawin berdasarkan hukum yang berlaku di Indonesia. ${ }^{9}$

Hal ini disebabkan itensitas komunikasi para remaja melalui sosial media dan berbagai media online sangat tinggi selama pandemi Covid-19. Mulai dari kebijakan belajar daring, pertemuanpertemuan dunia maya yang dilakukan demi menghambat laju penyebaran virus corona, ternyata menambahjumlah pertemanan dan komunikasi, yang selanjutnya berbuah komitmen untuk membina hubungan yang lebih dari sekedar pertemanan, bahkan banyak yang berakhir dengan pernikahan dini. Dosen Departemen Hukum Perdata Fakultas Hukum Universitas Padjadjaran Susilowati Suparto sebagaimana dikutip dari laman Kompas mengatakan, faktor peningkatan angka pernikahan dini di masa pandemi Covid-19 salah satunya diakibatkan persoalan ekonomi.

Kehilangan mata pencaharian selama pandemi berdampak pada sulitnya kondisi ekonomi keluarga. "Para orang tua dari kalangan pekerja tersebut sering kali mengambil alternatif berupa jalan pintas, dengan menikahkan anaknya di usia dini, karena beranggapan dapat meringankan beban keluarga," demikian antara lain yang dipaparkan Susilowati dalam Webinar "Dispensasi Nikah pada Masa Pandemi Covid-19: Tantangan Terhadap Upaya Meminimalisir Perkawinan Anak di Indonesia”

\footnotetext{
7 Majalah Orami, "Moms, Ketahui Tanda Hingga Cara Mencegah Pubertas Dini Pada Anak," Orami, 2021, https://www.orami. co.id/magazine/pubertas-dini.

8 St. Rahmah Syam Ali, Dampak Covid 19 Terhadap Sosial Ekonomi Masyarakat Indonesia, Dalam Bunga Rampai Pandemi (Menyingkap Dampak Sosial COVID-19) Bunga Rampai Pandemi “Menyingkap Dampak -Dampak Sosial Kemasyarakatan Covid- 19” (Parepare: IAIN Parepare Nusantara Press, 2020), 52-3.

9 Dwi Hadya Jayani, “Wabah Pernikahan Dini Di Tengah Pandemi Dan Dampak Buruknya,” katadata.co.id, 2021, https://katadata. co.id/muhammadridhoi/analisisdata/5ff7cb5cdf279/wabah-pernikahan-dini-di-tengah-pandemi-dan-dampak-buruknya.
} 
yang digelar FH Unpad, Jumat (3/7/2020), seperti dilansir dari laman Unpad. Kurangnya pengawasan orangtua terhadap anak terkait adanyan kebijakan penutupan sekolah dan pemberlakuan belajar di rumah, juga diantara pemicu maraknya pernikahan dini. Susilowati mengatakan, bahwa aktivitas belajar di rumah membuat para remaja memiliki keleluasaan dalam bergaul di lingkungan sekitarnya. Hal ini dapat terjadi, apabila pengawasan orangtua sangat lemah terhadap anaknya. ${ }^{10}$

Sampai di sini pernikahan dini dianggap sebagai solusi untuk menghindari pergaulan bebas. Namun pada sisi yang lain, keadaan pasangan muda yang belum memiliki kesiapan mental dan finansial, banyaknya pengangguran dan semakin sulitnya mencari lapangan pekerjaan saat pandemi, terutama bagi suami yang akan memikul tanggung jawab nafkah, akan menimbulkan persoalan baru yang dapat mengancam eksistensi pernikahan. Terlebih jika si isteri segera hamil setelah menikah. Sehingga tidak hanya problem finansial dan kesiapan mental, kondisi pandemi juga berpotensi mengancam kesehatan ibu dan anak.

Karena itu dibutuhkan semacam kesepakatan pra nikah untuk menunda kehamilan bagi pasangan yang akan melakukan pernikahan dini. Hal ini bertujuan untuk mewujudkan kemaslahatan yang diinginkan dari sebuah pernikahan, dan menghindari hal-hal buruk yang dapat mengancam eksistensi pernikahan tersebut. Namun yang menjadi persoalan adalah, bagaimana (meyakinkan) kesepakatan itu (benar-benar) dilakukan, dan bagaimana alternatif solusi yang harus ditempuh, jika pasangan tersebut menolak membuat kesepakatan.

Penelitian ini adalah penelitian hukum normatif. Penelitian hukum normatif adalah suatu proses untuk menemukan aturan-aturan hukum, prinsip-prinsip hukum, maupun doktrin hukum guna menjawab isu-isu hukum yang dihadapi. ${ }^{11}$ yang tergolong ke dalam penelitian klinis, yaitu penemuan hukum syar'i guna menjawab kasus tertentu, dalam hal ini adalah kasus-kasus pernikahan dini yang menjadi fenomena baru selama pandemi Covid-19. Penelitian klinis disebut juga sebagai penemuan hukum syar'i untuk menemukan hukum in concrito guna menjawab suatu kasus tertentu. ${ }^{12}$ Datadata yang digunakan dalam penelitian ini adalah data sekunder, karena diperoleh dari tangan kedua, yaitu berbagai literatur yang berhubungan dengan tema penelitian.

Berdasarkan sumbernya data tersebut dapat dibagi dua, yaitu: sumber primer dan sumber sekunder. Sumber primer adalah sumber utama, yang diperoleh dari berbagai literatur hukum Islam yang membahas tentang pernikahan, terutama yang berhubungan dengan ketentuan umur pasangan yang akan menikah, serta kajian tentang teori maslahah dan ketentuan mengenai syarat dan batasannya dalam Usul Fiqh.

Adapun sumber sekunder berupa data dan informasi dari tulisan-tulisan di berbagai media sosial dan media online yang membahas tentang fenomena pernikahan dini di masa pandemi yang akan digunakan untuk membantu melakukan analisis data-data dari sumber primer. Data dan informasi tersebut diperoleh dengan bantuan mesin pencari dengan menggunakan kata kunci yang berhubungan dengan tema penelitian, terutama yang menjelaskan fenomena pernikahan dini sejak awal pandemi hingga penelitian ini dilakukan. Awal pandemi di Indonesia diketahui dari Konfirmasi kasus Covid-19 pertama di Indonesia yang diumumkan langsung oleh Presiden Joko

\footnotetext{
10 Ayunda Pininta Kasih, "Pakar Unpad: Angka Pernikahan Dini Melonjak Selama Pandemi,” Kompas, 2020, https://edukasi. kompas.com/komentar/2020/07/08/131828971/pakar-unpad-angka-pernikahan-dini-melonjak-selama-pandemi.

11 Peter Mahmud Marzuki, Penelitian Hukum (Jakarta: Kencana, 2011), 35.

12 Syamsul Anwar, Metodologi Hukum Islam, n.d., 48-9.
} 
Widodo didampingi Menteri Kesehatan Terawan Agus Putranto. Pengumuman tersebut dilakukan di Istana Kepresidenan, Jakarta, pada 2 Maret 2020. ${ }^{13}$

Data-data yang sudah ada, akan dianalisis dengan menggunakan pendekatan maslahat/maqashid al-syari'ah, yang menitikberatkan pada tercapainya aspek tujuan hukum dan terlindunginya Hak Asasi Manusia, terutama yang berhubungan dengan hak kebebasan reproduksi, dan relevansinya dengan ketentuan fiqh dan hukum Islam yang sudah ada, serta kemungkinannya untuk menghasilkan ketentuan hukum baru.

\section{Melacak Hakikat Pernikahan Dini}

Untuk menjelaskan pernikahan dini, dibutuhkan kajian yang berhubungan dengan kriteria dewasa dalam ilmu psikologi. Sebagaimana dijelaskan oleh Erik Erikson salah seorang tokoh psikologi, bahwa pada masa pada masa dewasa awal terdapat salah satu tahap perkembangan sosio-emosional yang disebut Intimacy Vs Isolation. Intimacy adalah sebuah keadaan dimana seseorang mengembangkan hubungan intim dengan pasangannya. Dalam keadaan tersebut, mereka kehilangan jati diri mereka sekaligus menemukannya pada diri orang lain. Namun ketika seseorang berada pada tahap yang sebaliknya, yaitu isolation maka, maka dia justeru akan sulit atau bahkan tidak mengembangkan hubungan intim dengan siapapun. ${ }^{14}$ dan ketentuan lebih jelasnya dalam hukum positif. Dalam hukum positif usia minimal seseorang dikaitkan dengan kebolehannya mewujudkan keinginan untuk menikah dan sudah ditentukan, yaitu calon suami sekurang-kurangnya berumur 19 tahun dan calon isteri sekurang-kurangnya berumur 16 tahun. ${ }^{15}$

Kriteria dewasa tersebut dibutuhkan untuk menentukan atau mengukur tingkat kedewasaan seseorang, sehingga ia dapat dibedakan dengan anak-anak. Hal ini penting untuk diperhatikan, karena Undang-Undang Perkawinan yang sudah ada membatasi umur minimal pasangan yang akan menikah. Artinya ketentuan ini mengikat seluruh warga negara yang akan melangsungkan pernikahan, serta akan berlaku terus-menerus, sampai ada ketentuan lain yang mengubahnya. Padahal belum tentu semua pasangan yang akan menikah di bawah umur minimal yang sudah ditentukan dalam UU tersebut, dapat dikategorikan anak-anak, jika mengacu pada kriteria dewasa dalam ilmu psikologi. Pertimbangan psikologis ini tidak boleh dibaikan, karena kedewasaan dalam literatur fiqh, sangat berhubungan dengan tanggung jawab dan kemampuan memberi nafkah. ${ }^{16}$

Hal-hal seperti inilah yang akan menjadi pertimbangan, terutama pada saat pasangan yang akan melakukan pernikahan dini tersebut mengajukan permohonan dispensasi. Dispensasi adalah pemberian hak kepada seseorang untuk menikah meskipun usianya belum mencapai batas minimal 19 tahun berdasarkan UU No. 16 Tahun 2019, sebagai hasil revisi dari UU No. 1 Tahun 1974, dan telah berlaku sejak 15 Oktober 2019. Pada Pasal 7 ayat (2) UU Perkawinan yang baru menegaskan bahwa dispensasi perkawinan dapat diberikan atas alasan mendesak. UU Perkawinan menjelaskan bahwa

\footnotetext{
13 KOMPAS, "Perjalanan Pandemi Covid-19 Di Indonesia, Lebih Dari 100.000 Kasus Dalam 5 Bulan,” kompas.com, 2020, https://www.kompas.com/tren/read/2020/07/28/060100865/perjalanan-pandemi-COVID-19-di-indonesia-lebih-dari-100.000kasus-dalam-5?page=all.

14 Angela, "Pengembangan Intimacy Pada Masa Dewasa Awal," binus.ac.id, 2015, https://psychology.binus.ac.id/2015/07/02/ pengembangan-intimacy-pada-masa-dewasa-awal/.

15 Undang-Undang Perkawinan No 1 Tahun 1974 Pasal 7 Ayat (1), dan Kompilasi Hukum Islam Pasal 15 ayat 1.

${ }^{16}$ Musthafa Dib al-Bugha, Muthafa al-Khin, ‘Ali Sybarji, Al-Fiqh Al-Manhaji ‘Ala Madzhab Al-Imam Al-Syafi'i, 333.
} 
alasan mendesak adalah keadaan tidak ada pilihan lain dan sangat terpaksa harus dilangsungkan perkawinan. ${ }^{17}$

Pada saat ini Covid-19 bukan hanya membahayakan kesehatan, tapi juga menimbulkan problem sosial, termasuk dalam bidang ekonomi. Lebih dari itu, wabah Covid-19 ini telah melanda dunia, sehingga WHO menetapkannya sebagai pandemi. World Health Organization (WHO), Telah Menetapkan Wabah Covid-19 atau Virus Corona (SARS Cov-2) Menjadi Pandemi Global. Peningkatan Status Ini Diumumkan Langsung Oleh Direktur Jenderal WHO Tedros Ghebreyesus di Jenewa, Swiss pada 11 Maret 2020. Penetapan status pandemi ini disebabkan oleh penyebaran yang sangat cepat dan luas hingga ke wilayah yang jauh dari pusat wabah. ${ }^{18}$

Berbagai problem itu seringkali menimbulkan keguncangan dalam kehidupan rumah tangga. Banyak pasangan yang memutuskan untuk berpisah, dengan meninggalkan anak-anak yang masih membutuhkan kasih sayang dan pendidikan. Sesuai dengan pernyataan Menag Fachrul Razi dalam rapat bersama Komisi VIII DPR/MPR RI, di kompleks parlemen, Senin (23/11/2020), ia menyataakan bahwa "Angka perceraian meningkat selama COVID" ${ }^{19}$ Kedewasaan dalam menyikapi berbagai persoalan rumah tangga ini sangat dibutuhkan, sehingga masing-masing pihak baik suami maupun isteri tidak mudah emosional dan cenderung mengambil tindakan-tindakan yang kurang dipertimbangkan. Sehingga muncul wacana untuk membuat kesepakatan menunda kehamilan bagi pasangan yang melakukan pernikahan dini di masa pandemi. Hal ini bertujuan untuk mengantisipasi berbagai hal buruk yang ditimbulkan dan akan dialami oleh anak yang akan dilahirkan.

Pertimbangan-pertimbangan seperti ini sangat jelas bertumpu pada kemaslahatan suami, isteri, dan anak yang dilahirkan. Akan tetapi pertimbangan maslahat semata, terkadang tidak membuat apa yang dianggap maslahat itu sejalan dengan kehendak syari'. ${ }^{20}$ Sehingga dalam hal ini maslahat yang akan diwujudkan, mesti dipahami sebagai kemaslahatan yang dikehendaki syari', atau yang dikenal dengan maqashid al-syari'ah. ${ }^{21}$ Dengan kata lain kesepakatan menunda kehamilan tersebut harus mempertimbangkan terealisasinya maqashid al-syari'ah, yaitu; menjaga agama, menjaga jiwa, menjaga akal, menjaga keturunan, menjaga harta.

Adapun yang dimaksud dengan menunda kehamilan, adalah suatu upaya yang dilakukan secara sengaja untuk menunda atau menghalangi terjadinya proses pembuahan dalam rahim, sehingga menyebabkan tertundanya kehamilan, atau keinginan untuk memiliki anak. Secara teknis, istilah yang digunakan untuk mengungkapkan keputusan atau tindakan menunda kehamilan tersebut, memiliki istilah yang berbeda-beda. Dalam terminologi fiqh tindakan itu disebut 'azl. Sedangkan dalam regulasi peraturan perundang-undangan sering disebut dengan kotrasepsi, atau pengaturan kehamilan. Sementara BKKBN sebagai institusi resmi yang melakukan pendampingan, memberikan pembekalan, dan memandu penggunaan alat kotrasepsi, sering menyebutnya dengan Keluarga Berencana $(\mathrm{KB}){ }^{22}$

17 “Undang-Undang No. 16 Tahun 2019" (n.d.). Pasal 7 Ayat 2.

18 Kompas, "Who Tetapkan Wabah Virus Corona Sebagai Pandemi Global,” Kompas.Com, 2020, Https:/Www.Kompas.Tv/ Article/70893/Who-Tetapkan-Wabah-Virus-Corona-Sebagai-Pandemi-Global.

19 Detik, "Menag: Angka Perceraian Meningkat Selama Covid-19," detik.com, 2020, https://news.detik.com/berita/d-5266413/ menag-angka-perceraian-meningkat-selama-Covid-19.

20 Al-Ghazali, Al-Musthafa Min 'ilm Al-Ushul, Tahqiq Muhammad Sulayman Asyqar (Beirut: Al-Risalah, 1997), 416-7.

21 Al-Ghazali., 414-6.

22 Faisal, Somantri, Muhamad Dani, Dahwadin, “Analisa Hukum Menunda Kehamilan Perkawinan Usia Dini Perspektif Istihsan Sebuah Upaya Membangun Keluarga Berkualitas,” Mahkamah : Jurnal Kajian Hukum Islam 3, no. 2 (2018), 212-3. 
Jika kesepakatan penundaan kehamilan tersebut dibutuhkan, maka hal selanjutnya yang harus dikaji adalah bentuk kesepakatan yang akan dibuat. Karena, jika dilihat dari tujuannya, maka kesepakatan tersebut semestinya sudah dibuat atau terjadi sebelum pernikahan dini dilakukan. Dalam hal ini erat kaitannya dengan ketentuan syarat tambahan di luar syarat-syarat pernikahan yang sudah ada, baik yang terdapat dalam literatur fiqh maupun dalam UU Perkawinan. Wahbah alZuhayli dalam Satria Efendi menyebut syarat tambahan ini dengan istilah syarat tawsiqy. ${ }^{23}$

Kajian tentang syarat ini dilakukan untuk melihat, sejauhmana keabsahan dari persyaratan tambahan tersebut, beserta kriteria yang harus dipenuhi. Termasuk pertimbangan apakah syarat itu melanggar HAM atau tidak, terutama dalam hak kebebasan reproduksi. Hak asasi manusia (HAM) tidak terlepas dari pembicaraan tentang perlindungan (to protext), penghormatan (to respect), dan pemenuhan (to fullfil) pada setiap orang tanpa pengecualian, HAM juga bersifat universal dan mutlak artinya berlaku untuk semua orang di manapun dan kapanpun. Pasal 1 Anka 1 UU HAM mendefinisikan "Hak Asasi Manusia adalah seperangkat hak yang melekat pada hakikat dan keberadaan manusia sebagai mahkluk Tuhan Yang Maha Esa dan merupakan anugerah-Nya yang wajib dihormati, dijunjung tinggi dan dilindungi oleh negara, hukum, Pemerintah, dan setiap orang demi kehormatan serta perlindungan harkat dan martabat manusia" 24

Secara biologis organ seks laki-laki maupun perempuan baru mencapai ukuran matang di akhir masa remaja, sekitar umur 21 atau 22 tahun. sehingga pernikahan yang dilakukan pada usia belasan tahun bukan merupakan pernikahan yang dilakukan pada masa reproduksi yang sehat, karena organ seks belum mengalami kematangan. Meskipun perempuan pada usia belasan secara fisiologik dapat hamil dan melahirkan, tetapi secara medis dan psikologi belum cukup matang untuk melahirkan dan mengasuh anak. ${ }^{25}$ Terdapat perbedaan rentang usia antara laki-laki dan perempuan dalam mencapai puncak kematangan jasmani, di mana anak laki-laki mencapai puncak kematangan jasmani di usia 2124. Sedangkan anak perempuan mencapai puncak kematangan jasmani di rentang usia 19-21 tahun. Dalam psikologi perkembangan, usia di bawah 18 tahun tergolong ke dalam kelompok usia yang belum siap dan belum matang untuk berumah tangga. Mereka masih berada dalam naungan perlindungan orangtua. Hal ini dapat dipahami, karena di usia 18 tahun mereka masih harus bersekolah. ${ }^{26}$

Adapun secara psikologis menurut Andrson (dalam Mappiare), seseorang dapat dikatakan telah dewasa: ketika ia sudah berorientasi pada tugas, memiliki tujuan yang jelas serta kebiasaankebiasaan yang terarah, mampu mengendalikan perasaan pribadi, memiliki sikap objektif, memiliki rasa tanggung jawab, dan kemampuan menyesuaikan diri dengan situasi-situasi baru. ${ }^{27}$ Namun pada kenyataannya antara kematangan jasmani dengan kondisi psikologis seseorang tidak selalu sejalan dan saling berhubungan. Banyak anak-anak usia belasan tahun, yang sebenarnya masih harus bersekolah dan berada dalam naungan perlindungan orang tuanya, tapi sudah mandiri, memiliki rasa tanggung jawab, dan dapat mengambil keputusan sendiri. Baik mereka yang berasal dari latar belakang keluarga kurang mampu, karena harus bekerja membantu orang tua mencari nafkah, maupun mereka yang berasal dari latar belakang keluarga yang berkecukupan, namun memilih untuk hidup mandiri.

\footnotetext{
${ }^{23}$ Zein Satria Effendi M, Problematika Hukum Keluarga Islam Kontemporer, Analisis Yurisprudensi Dengan Pendekatan Ushuliyah (Jakarta: Kencana Prenada Group, 2015), 35.

24 Undang-Undang No. 39 Tahun 1999 Tentang Hak Asasi Manusia. Pasal 1 Angka 1.

25 E. B. Hurlock, Psikologi Perkembangan: Buatu Pendekatan Sepanjang Rentang Kehidupnn,Terj. Istiwidayanti Dan Soedjarwo (Jakarta: Erlangga, 1990), 206-7.

26 Andi Mappiare, Psikologi Orang Dewasa, Usaha Nasional, n.d, 17.

27 Amita Diananda, "Psikologi Remaja Dan Permasalahannya," Journal Istighna 1, no. 1 (2019), 116-133.
} 
Dalam literatur figh, karena tujuan pernikahan pada dasarnya adalah untuk meneruskan keturunan, maka kriteria dewasa sangat berhubungan dengan kematangan biologis, yaitu; keadaan jasmani seseorang, yang sudah memungkinkannya untuk menghasilkan keturunan (reproduksi). Sehingga dewasa dalam perspektif figh sering diidentikkan dengan baligh, yaitu usia di mana seorang laki-laki sudah mengeluarkan sperma melalui mimpi basah, dan wanita sudah mengalami haidh, sebagai pertanda bahwa rahimnya siap untuk dibuahi/hamil. Terlepas dari perbedaan pendapat para ulama mazhab, pada intinya laki-laki dan perempuan yang mencapai usia baligh itu masih dalam hitungan belasan tahun. Namun terkait dengan pernikahan dalam literatur fiqh, terutama fiqh mazhab, tidak ditemukan penjelasan khusus yang menyatakan bahwa pasangan yang akan menikah harus mencapai usia baligh.

Dengan demikian dapat dipahami, bahwa ketentuan resmi tentang batasan minimal umur pasangan yang akan menikah pada akhirnya sangat diperlukan. Hal ini guna menghilangkan perbedaan dalam menentukan layak atau tidaknya seseorang, baik laki-laki maupun perempuan dikategorikan sebagai orang dewasa, dan siap untuk menikah. Sehingga lahirlah UU Perkawinana tahun 1974, yang menjelaskan batasan minimal umur pasangan yang akan melakukan pernikahan, yakni calon suami sekurang-kurangnya berumur 19 tahun dan calon isteri sekurang-kurangnya berumur 16 tahun.

Dari ketentuan ini diketahui, bahwa pasangan yang menikah di usia kurang dari ketentuan yang sudah ada dalam UU Perkawinan, adalah pasangan yang belum dianggap dewasa, atau dapat dimasukkan ke dalam kategori pasangan yang melakukan pernikahan dini. Namun ketentuan ini tentu tidak dapat diterapkan secara kaku, karena faktanya pernikahan dini tidak dapat dihindari dan masih banyak terjadi, mengingat kedewasaan secara biologis maupun psikologis, yang disertai keinginan kuat untuk menikah itu bisa saja terjadi pada laki-laki dan perempuan yang belum mencapai batas usia minimal yang dibolehkan oleh UU Perkawinan.

Menutup sama sekali peluang bagi mereka untuk menikah, dikhawatirkan akan menimbulkan persoalan baru, terutama di tengah maraknya pergaulan bebas di kalangan remaja. Karena itu lahirlah UU No. 16 Tahun 2019 sebagai hasil revisi dari UU Perkawaninan No. 1 Tahun 1974, dimana UU Perkawinan yang baru tersebut mengizinkan pasangan muda tapi sudah sangat ingin menikah, untuk meminta dipensasi keringanan kepada KUA setempat.

\section{Kesepakatan Pasangan Muda Untuk Menunda Kehamilam di Masa Pandemi}

Jumlah pernikahan di usia dini mengalami peningkatan selama masa pandemi virus Corona (Covid-19). Melonjaknya pernikahan dini ini tak hanya terjadi di Indonesia, tapi juga di tingkat global pada beberapa negara yang ada di dunia. Pernikahan pasangan remaja, seperti yang terjadi di NTB, sebagaimana dilansir detik.com, berawal dari kebijakan sekolah daring, akibat tidak adanya pembelajaran tatap muka karena pandemi Corona. Pernikahan dini itu diduga akibat dari aktivitas chatting yang dilakukan para pelajar selama sekolah secara daring. ${ }^{28}$

Namun faktor ketidaksiapan untuk menikah, terutama dari aspek mental dan finansial, dalam situasi pandemi yang banyak memunculkan problem sosial, menimbulkan kekhawatiran tersendiri.

28 Detik, "Gejala Global Pernikahan Dini Melonjak Di Masa Pandemi,” detik.com, 2020, https://news.detik.com/berita/d-5180276/ gejala-global-pernikahan-dini-melonjak-di-masa-pandemi. 
Terlebih jika pasangan muda tersebut tidak menunda kehamilan dan segera memiliki anak. Padahal kehamilan di usia yang relatif sangat muda, sangat beresiko. Apalagi kehamilan tersebut di tengah pandemi yang mengancam kesehatan. Pandemi corona bisa membuat seorang Ibu kehilangan kesempatan untuk memberikan nutrisi terbaik bagi bayi yang baru dilahirkannya.

Seperti kasus Nomi Hermawan yang batal melakukan inisiasi menyusu dini (IMD). Padahal proses memberikan air susu ibu dan juga langkah penting bagi bayi belajar menyusu. Sebagaimana disebutkan dalam berita yang ditayangkan dalam laman bbc. com Indonesia, sesaat setelah dilahirkan, bayi Nomi langsung dibawa ke ruang bayi agar terhindar dari ancaman penularan virus corona. Nomi dan bayinya terpaksa harus berpisah selama kurang lebih 24 jam. Padahal bayi tersebut semestinya berada di dekat ibunya selama 24 jam pertama kelahirannya, jika tidak ada kendala medis. Persalinan yang dijalani Nomi ternyata juga berbeda, dimana dokter dan perawat yang menanganinya seluruhnya mengenakan alat perlindungan diri (APD) lengkap, seperti hazmat, masker, dan face shield (penutup muka). Meskipun ia masih merasa beruntung masih bisa didampingi suami saat persalinan. Meski, suaminya harus memakai APD. ${ }^{29}$

Bahkan Angka kematian ibu hamil dan melahirkan meningkat selama pandemi Covid-19, seperti yang terjadi di Kabupaten Sukoharjo. Salah seorang tenaga medis bernama Agus menyebutkan, banyak faktor yang mempengaruhi. Salah satunya adalah faktor ekonomi. "Kondisi ekonomi secara tidak langsung juga menyebabkan, karena pedarahan berawal dari kurangnya asupan gizi," ujarnya seperti diberitakan Kantor Berita RMOL Jateng..$^{30}$ Pada masa pandemi Covid-19 kehamilan tidak direncanakan (KTD) juga memiliki dampak yang luas seperti meningkatkan kasus aborsi, meningkatkan risiko kematian ibu dan anak, kasus anemi serta malnutrisi pada ibu hamil dan janin, bayi lahir prematur, berat Bayi Lahir Rendah (BBLR) dan kurangnya kasih sayang dan pengasuhan karena anak tersebut lahir tidak diinginkan. ${ }^{31}$

Kekhawatiran terhadap dampak negatif yang ditimbulkan oleh pernikahan dini, terutama di era pandemi, pada dasarnya dapat diatasi dengan membuat kesepakatan pra-nikah. Kesepakatan tersebut bisa mengikat secara moral, yaitu: dalam bentuk komitmen yang disampaikan secara lisan oleh pasangan muda yang akan melakukan pernikahan dini, bisa juga mengikat secara yuridis, berupa kesepakatan tertulis yang ditandatangani oleh kedua belah pihak pasangan.

Dalam Undang-Undang Nomor 1 Tahun 1974 maupun kompilasi hukum Islam dijelaskan bahwa, isi Perjanjian Perkawinan dapat menyangkut segala sesuatu hal yang tidak bertentangan dengan ketentuan perjanjian secara umum, hanya saja perjanjian itu disahkan didepan Pegawai Pencatat Nikah. Isi Perjanjian Perkawinan sebagaimana diatur dalam Undang-Undang Nomor 1 Tahun 1974, menurut Abdul Kadir Muhammad dapat mengenai segala hal, sepanjang tidak melanggar batas-batas hukum, agama dan kesusilaan. Adapun isi Perjanjian Perkawinan itu meliputi : 1. Penyatuan harta kekayaan suami istri. 2. Penguasan, pengawasan dan perawatan harta kekayaan istri oleh suami. 3. Istri atau suami melanjutkan kuliah dengan biaya bersama. 4. Dalam perkawinan mereka sepakat untuk melaksanakan keluarga berencana (penundaan kehamilan). ${ }^{32}$

${ }^{29}$ Suara.com, "Beban Berlipat Ganda Bagi Perempuan Di Masa Pandemi Covid-19," suara.com, 2020, https://www.suara.com/ news/2020/04/19/124820/beban-berlipat-ganda-bagi-perempuan-di-masa-pandemi-COVID-19?page=5.

30 RMOL, “Angka Kematian Ibu Hamil Meningkat Selama Pandemi Covid-19,” kesehatan.rmol.id, 2020, https://kesehatan.rmol. id/read/2020/11/24/462590/angka-kematian-ibu-hamil-meningkat-selama-pandemi-Covid-19.

31 Indonesiabaik.id, "Posistif Hamil Di Tengah Corona Apa Risikonya," indonesiabaik.id, 2020, http://indonesiabaik.id/infografis/ positif-hamil-di-tengah-corona-apa-risikonya.

32 Bernhard I. M. Supit, "Pembatalan Nikah Menurut Hukum Kanonik Dalam Hubungannya Dengan Sistem Perundang Undangan di Indonesia," lex privatum 2, no. 1 (2015), 232-9. 
Substansi beserta rincian dari isi perjanjian perkawinan umumnya diserahkan kepada kedua mempelai/calon mempelai, berupa hal-hal yang berkaitan dengan upaya mengantisipasi semua masalah yang mungkin timbul dalam perkawinan dan khususnya bagi isteri. Karena itu isi perjanjian dapat berupa segala hal yang menjadi sumber tidak terpenuhinya hak isteri, yang diduga kuat akan menjadi sumber perlakuan diskriminatif atau kesewenangan suami.

Meskipun pada dasarnya, suami-isteri/calon suami-calon isteri dibebaskan dalam menentukan materi perjanjian, tapi tentu saja harus dipastikan isinya tidak bertentangan dengan aturan-aturan syari'at. ${ }^{33}$ Hal ini sejalan dengan ketentuan dalam Kompilasi Hukum Islam (KHI), Pasal 45 yang mengatur bahwa: "kedua calon mempelai dapat mengadakan perjanjian perkawinan dalam bentuk: Taklik talak, dan perjanjian lain yang tidak bertentangan dengan hukum Islam." ${ }^{34}$

Dalam Pasal 29 UU Perkawinan juga telah dijelaskan, bahwa perjanjian tersebut tidak boleh disahkan, jika isinya melanggar batas-batas hukum dan kesusilaan. Dengan demikian, segala hal sepanjang tidak bertentangan dengan hukum dan kesusilaan dapat dituangkan secara tertulis dalam perjanjian tersebut, seperti mengenai harta sebelum dan sesudah nikah atau setelah cerai, pendidikan dan pengasuhan anak, tanggung jawab dalam melakukan pekerjaan-pekerjaan rumah tangga, penggunaan nama, pembukaan rekening Bank, hubungan dalam keluarga, harta warisan, larangan melakukan tindak kekerasan, marginalisasi (membatasi hak untuk bekerja), subordinasi (pengecilan peran). Pelanggaran yang dilakukan suami, sangat tergantung dari detail isi perjanjian. Ketika suami ingkar janji (wanprestasi), maka telah melakukan pelanggaran perjanjian kawin. ${ }^{35}$

Dengan demikian berdasarkan UUP dan KHI, dapat dipahami bahwa Perjanjian Perkawinan tidak harus berhubungan dengan masalah harta, tetapi boleh berhubungan dengan hal-hal lain yang dianggap perlu dan penting guna mewujudkan kemaslahatan hidup berumah tangga agar tercipta keluarga yang bahagia dan terhindar dari masalah yang bisa menyebabkan perceraian. Justeru di sinilah letak urgensinya perjanjian perkawinan. Termasuk dalam hal ini adalah kesepakatan menunda kehamilan bagi pasangan yang melakukan pernikahan dini.

Terkait dengan kesepakatan menunda kehamilan yang tertuang dalam Perjanjian perkawinan, kesepakatan tersebut harus dibuat sebelum perkawinan berlangsung. Karena Perjanjian Perkawinan bukanlah taklik-talak. Hal ini sebagaimana disebutkan dalam penjelasan pasal 29 UU Perkawinan bahwa taklik-talak tidak termasuk dalam perjanjian perkawinan. Perjanjian perkawinan itu dibuat secara tertulis, seta persetujuan kedua belah pihak yang disahkan Pencatat Perkawinan. Setelah disahkan oleh Pegawai Pencatat Perkawinan, isinya akan mengikat para pihak, termasuk juga pihak ketiga yang tersangkut dengannya. Perjanjian perkawinan itu berlaku sejak perkawinan berlangsung, dan isinya tidak boleh diubah kecuali dengan persetujuan kedua belah pihak, dan tidak boleh merugikan pihak ketiga yang tersangkut. ${ }^{36}$

Dalam ajaran agama Islam, konsep menunda atau mencegah kehamilan (man'u al-hamli) bukan sesuatu yang baru. Karena usaha menunda kehamilan pernah dipraktikan oleh para sahabat semenjak zaman Nabi Muhammad SAW yang dikenal dengan istilah al-azl. Sebagaimana hadits

\footnotetext{
33 Abd. Rahman Ghazaly, Fiqh Munakahat, (Jakarta: Kencana, 2003), hlm. 121; Nilna Fauza and Moh Afandi, "Perjanjian Perkawinan Dalam Menjamin Hak-Hak Perempuan," Al-Manhaj:Journal of Indonesian Islamic Family Law 2, no. 1 (2020), 1.

${ }^{34}$ R.I, Kompilasi Hukum Islam., 29.

35 Iin Ratna Sumirat, "Pelanggaran Perjanjian Perkawinan Serta Akibat Hukumnya Analisis Hukum Positif Dan Hukum Islam," Journal of Materials Processing Technology 1, no. 1 (2018): 1-8.

36 Sumirat.
} 
Nabi yang diriwayatkan Bukhari dari Jabbir, "Kami melakukan al-'azl pada masa Nabi Muhammmad SAW, sedangkan ayat al- Quran masih diturunkan" (HR. Bukhari). Dalam riwayat Muslim dari Jabbir dituliskan bahwa, "Kami pernah melakukan al-a 'zl di masa Rasulullah SAW, kemudian berita itu sampai kepadanya, namun Rasulullah tidak melarang kami” (HR. Muslim).

Menurut Thariq al-Thawari, dalam perspektif hukum Islam perbuatan a'zl atau penundaan kehamilan yang dilakukan oleh pasangan perkawinan pada umumnya dilatarbelakangi oleh beberapa faktor, yaitu: pertama, menjaga kondisi kesehatan istri dan didasari oleh pertimbangan, jika ia hamil, kemudian melahirkan atau menyusui diduga akan mendatangkan bahaya terhadap dirinya maupun anak yang dikandung. Hal ini dilakukan harus berdasarkan hasil pertimbangan dan diagnosa dari pihak medis atau pihak yang dipercaya. Kedua, dilatarbelakangi oleh kekhawatiran bahwa, apabila pasangan tersebut memiliki anak tanpa memiliki bekal persiapan yang matang, mereka tidak akan mampu memberi pendidikan yang layak dan sesuai dengan tuntutan syara, sehingga memutuskan untuk melakukan penundaan kehamilan dengan tujuan agar terhindar dosa agama.

Ketiga, mempertimbangkan keadaan isteri yang sedang menyusui, sehingga apabila mereka melakukan hubungan seksual dan kemudian si isteri mengalami kehamilan, akan menghentikan pemberian air susu ibu (ASI) kepada anak, sehingga dikhawatirkan akan membahayakan anak yang sedang membutuhkannya. Keempat, seorang hamba sahaya yang tidak menginginkan anak keturunan dari hasil darah daging majikannya. Kelima, kondisi fisik istri yang lemah, ditakutkan apabila ia hamil akan mengakibatkan kesehatannya terganggu atau bahkan mendatangkan kematian. Keenam, kondisi isteri yang sedang mengalami kesuburan (ovulasi) sehingga suami dituntut untuk melakukan a'zl guna menunda masa kehamilan sementara waktu. ${ }^{37}$

Dalam perspektif HAM, membentuk keluarga dan melanjutkan keturunan merupakan suatu hak asasi manusia seperti yang telah disebut dalam Pasal 28B UUD 1945, namun dalam praktiknya perlu pertimbangan lain untuk menjamin keselamatan manusia itu sendiri (hak hidup) juga sebagai hak asasi. Dalam hal ini, jaminan tersebut khususnya hak kesehatan seksual dan reproduksi di antaranya "Memutuskan untuk memiliki anak atau tidak, dan kapan waktu yang tepat untuk memliki anak". ${ }^{38}$ Namun demikian, reproduksi penting direncanakan secara baik dan menyeluruh meliputi fisik, mental, dan kesejahteraan sosial. Menentukan waktu yang tepat mempunyai anak, jumlah anak, dan jarak antara anak yang dikehendaki adalah tindakan turunannya.

Disamping itu, memastikan kesehatan reproduksi merupakan sesuatu yang tidak bisa dinafikan sebagaimana telah diatur dalam Undang-Undang No. 23 tahun 1992 tentang kesehatan, bunyi Pasal 14 menyebutkan betapa penting jaminan kesehatan setiap ibu yang mengandung, jaminan kesehatan sebagai ibu mencakup kesehatan prakehamilan, pada saat hamil, pada saat persaslinan dan setelah persalinan dan masa di luar kehamilan. ${ }^{39}$ Dari si sini dapat dilihat bahwa reproduksi tidak dapat dibenarkan hanya alasan melanjutkan keturunan lalu mengabaikan kesehatan. Dalam Pasal 13 aturan tersebut juga menyinggung bagaimana pengaturan angka kelahiran dalam rangka mewujudkan keluarga yang sehat dan harmonis. Harmonis berkaitan erat dengan urusan ekonomi rumah tangga

37 Thariq al-Thawari, KB Secara Islam, (Solo: PT. Aqwam Media Profetik, 2007), hlm. 16-17; Muhamad Dani Somantri, Dahwadin Dahwadin, and Faisal Faisal, "Analisa Hukum Menunda Kehamilan Perkawinan Usia Dini Perspektif Istihsan Sebuah Upaya Membangun Keluarga Berkualitas," Mahkamah :Jurnal Kajian Hukum Islam 3, no. 2 (2018), 203.

38 PKBI, "Hak Asasi Manusia (HAM) Dan Hak Kesehatan Reproduksi," pkbi.or.id, 2015, https://pkbi.or.id/hak-asasi-manusiaham-dan-hak-kesehatan-seksual-reproduksi-hksr/.

39 “Undang-Undang No. 23 Tahun 1992 Tentang Kesehatan” (n.d.). Pasal 14. 
yang memadai, karena soal pangan merupakan kebutuhan dasar manusia yang tidak bisa ditunda keberadaannya, dengan kata lain pertimbangan ekonomi dan kesehatan patut dikedepankan dalam perencanaan reproduksi.

Jika dihubungkan dengan saat ini, pandemi yang belum berakhir dan telah menyisakan catatan penting bagi kehidupan manusia dari berbagai sisi seperti sosial, pendidikan, ekonomi, kesehatan, hingga ancaman kematian termasuk bagi pasangan muda yang baru melangsungkan pernikahan dan ingin segera mempunyai anak. Karena ancaman itu sangat rentan pada saat ini.

Ancaman yang paling rentan itu adalah jaminan ekonomi dan kesehatan yang saling berkelindan menjadi momok besar saat ini. Kesulitan ekonomi yang turut menimpa ekonomi keluarga baru memebuat suplai makanan bergizi dan pemeriksaan kesehatan menjadi terbatas diterima oleh sang ibu dan anak yang tengah dikandungnya yang seharusnya tercukupi, namun karena keterbatasan ekonomi dan akses pelayanan kesehatan pada saat ini kenyataan pahit itu terpaksa diterima. Selanjutnya, pun memungkinkan pada saat pemeriksaan kesehatan dilakukan akan terjadi kontak dengan orang lain yang tidak dapat dipastikan terbebas dari pandemi atau tidak, dan tidak menutup kemungkinan untuk menimbulkan klaster baru pandemi, oleh karena itu penundaan kehamilan dapat dinilai sebagai bentuk apresiasi mendukung perlindungan, penghormatan dan pemenuhan hak asasi manusia khususnya jaminan ekonomi dan kesehatan bagi keluarga baru yang pernikahan dini.

\section{Kesepakatan Pra-Nikah, Kedudukan, dan Akibatnya dalam Perspektif Hukum Islam}

Segala sesuatu yang harus ada dan dipenuhi sebelum melakukan suatu perbuatan hukum, dalam istilah usul fiqh disebut dengan syarat..$^{40}$ Terpenuhi atau tidaknya syarat-syarat yang sudah ditentukan berpengaruh pada sah atau batalnya suatu perbuatan. Perbedaan tajam antara syarat syar'i dengan tawsiqy, dalam sejarah perkembangan hukum Islam, terlihat sejak adanya peraturanperaturan tambahan yang dibuat oleh undang-undang di suatu negara. Lebih dari itu syarat tawsiqy tersebut pada intinya tidak berpengaruh terhadap sah atau batalnya pernikahan. ${ }^{41}$ Dengan kata lain, tidak terpenuhinya syarat-syarat nikah, bisa menyebabkan pernikahan tersebut dianggap rusak (fasid), dan dapat dijadikan alasan untuk membatalkan sebuah pernikahan.

Adapun syarat, dalam hukum Islam dapat diabagi ke dalam dua bentuk: pertama, yang disebut dengan syarat syar'i, yaitu: syarat-syarat yang telah ditetapkan oleh syari'at, dan yang kedua disebut syarat tawsiqy, yaitu: syarat-syarat tambahan, diluar syarat-syarat yang telah ditetapkan oleh syari'at. ${ }^{42}$ Penambahan syarat di luar dari apa yang telah ditetapkan oleh syara' ini dilakukan berdasarkan pertimbangan maslahat, serta tidak berlaku secara umum. Artinya dapat dipahami bahwa: syarat tawsiqy ini dibuat atas dasar pertimbangan tertentu dan untuk kasus tertentu.

Berbeda dengan syarat syar'i, syarat tawsiqy tidak berhubungan dengan keabsahan suatu perbuatan hukum. Akan tetapi terpenuhi atau tidaknya syarat tawsiqy ini dapat berhubungan dengan perbuatan hukum lainnya, sehingga bisa menghalangi atau mengharuskan seseorang melakukan suatu perbuatan hukum.

\footnotetext{
40 Ali Jum'ah, Tarikh Ushul Al-Fiqh (Kairo: Dar al-Maqtham li al-Nasyr wa al-Tawzi', 2014), 56.

41 Ali Jum'ah, Tarikh Ushul Al-Figh., 37.

42 Satria Effendi M, Problematika Hukum Keluarga Islam Kontemporer, Analisis Yurisprudensi Dengan Pendekatan Ushuliyah., 35.
} 
Perbuatan pasangan yang melanggar kesepakatan untuk menunda kehamilan, tidak berhubungan dengan keabsahan pernikahan tersebut, akan tetapi mengharuskan atau dapat menghalangi seseorang untuk melakukan perbuatan hukum sesuai kesepakatan bersama, seperti: membatalkan perkawinan, bercerai, suami boleh menikah lagi, atau sebaliknya tidak boleh bercerai dan meninggalkan keluarga. Terhadap pihak yang melanggar kesepakatan ini, bisa diberikan sanksi atau mengakibatkan lahirnya hak dan kewajiban hukum lainnya, karena yang bersangkutan telah melakukan pelanggaran atas kesapakatan yang telah dibuat dan disetujui bersama.

Mengenai pelanggaran terhadap Perjanjian Perkawinan ini, dalam KHI tidak banyak disinggung. Pada bab VII mengatur tentang perjanjian perkawinan, dari delapan Pasal yang ada di dalmnya, frasa "pelanggaran perjanjian kawin", secara redaksional hanya disebut satukali. Frasa tersebut terdapat dalam Pasal 51 yang berbunyi: "Pelanggaran atas perjanjian perkawinan memberi hak kepada isteri untuk meminta pembatalan nikah atau mengajukannnya sebagai alasan gugatan perceraian ke Pengadilan Agama." Namun kata "pelanggaran" dalam ketentuan Pasal tersebut, baik pengertian maupun tingkatannya tidak disebutkan secara jelas dan gamblang. Jika dilihat secarabahasa, "pelanggaran" berasal dari kata dasar "langgar". Sehingga "pelanggaran" bermakna "perbuatan (perkara) melanggar". Dalam bahasa hukum, pelanggaran perjanjian disebut wanprestasi, atau dalam ungkapan lain, disebut juga dengan istilah"ingkar janji”. ${ }^{43}$

Pelanggaran atau perbuatan yang mengingkari isi Perjanjian perkawinan ini, sebagaimana taklik talak, pada dasarnya juga dapat dijadikan sebagai alasan perceraian seperti dinyatakan dalam KHI pasal 51, bahwa pelanggaran atas perjanjian perkawinan memberi hak kepada isteri untuk meminta membatalkan pernikahan atau mengajukan alasan gugatan perceraian ke Pengadilan Agama. ${ }^{44}$

Terkait dengan kesepakatan menunda kehamilan pada kasus pernikahan dini, perceraian bukanlah solusi yang tepat untuk dijadikan sebagai sanksi pelanggaran terhadapnya. Karena tujuan menunda kehamilan bagi pasangan yang melakukan pernikahan dini, pada dasarnya bertujuan untuk menghindari hal-hal yang dapat mengancam eksistensi perkawinan, dan dapat menyebabkan terlantarnya anak yang dikandung atau dilahirkan. Hal itu disebabkan oleh berbagai permasalahan yang muncul akibat dari ketidaksiapan hamil, dan melahirkan dalam siatuasi pandemi. Karena itu dibutuhkan keterlibatan pihak ketiga dalam membuat kesepakatan tersebut.

Dalam hal ini pihak ketiga yang dimaksud adalah orang tua yang meminta dispensasi agar dapat menikahkan anaknya. Sebagai pihak yang meminta dispensasi nikah, orang tua semestinya dilibatkan dalam kesepakatan menunda kehamilan di masa pandemi. Hal ini bertujuan agar pelanggaran terhadap perjanjian yang menyebabkan kehamilan, akan menjadi tanggung jawab bersama. Sehingga dengan demikian, berbagai kekhwatiran dan hal buruk yang pada awalnya ingin dihindari, namun pada akhirnya benar-benar terjadi, dapat dihadapi dan dicarikan solusinya secara bersama-sama.

Dalam kondisi seperti ini orang tua tidak dibenarkan sepenuhnya menyalahkan anak atau menantunya, apalagi memisahkan keduanya sebagai sanksi terhadap pelanggaran yang mereka lakukan. Justeru yang harus dilakukan oleh orang tua yang telah mengambil keputusan untuk menikahkan anaknya pada usia dini tersebut, adalah turut serta dan berupaya sedapat mungkin memberikan bantuan, agar eksistensi perkawinan anaknya tidak terancam, serta pengasuhan dan pemeliharaan anak yang dilahirkan menjadi lebih terjamin. Sehingga dengan demikian tujuan dari

\footnotetext{
${ }_{43}$ Sumirat, "Pelanggaran Perjanjian Perkawinan Serta Akibat Hukumnya Analisis Hukum Positif Dan Hukum Islam."
}

${ }^{44}$ Sumirat. 


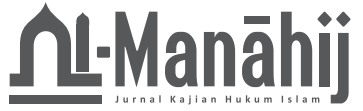

disyari'atkannya perkawinan dalam Islam, yaitu melindungi, dan memelihara keturunan (hifzu alnasl) dapat direalisasikan pada pasangan yang melakukan pernikahan dini.

\section{Penutup}

Dari berbagai pembahasan tentang kesepakatan menunda kehamilan bagi pasangan yang melakukan pernikahan pada usia dini di atas dapat dismpulkan antara lain:

Pernikahan dini adalah pernikahan yang dilakukan oleh pasangan di bawah umur, yaitu: mereka yang menikah pada usia kurang dari batas minimal yang telah ditetapkan dalam UU Perkawinan No. 1 tahun 1974 dan Kompilasi Hukum Islam (KHI). Secara fisik dan psikologis pasangan yang melakukan pernikahan dini ini bahkan belum memasuki masa dewasa awal, sehingga dianggap belum matang dan cukup siap menghadapi berbagai problem rumah tangga. Namun demikian, kondisi fisik dan psikis setiap anak tentu tidak sama. Sehingga tidak menutup kemungkinan, pasangan yang menikah di usia yang belum mencapai batas usia minimal sebagaimana ditetapkan UU, adalah pasangan yang telah dewasa, minimal memasuki tahap dewasa awal. Di sinilah diperlukannya izin mengajukan dispensasi nikah, agar pasangan menikah tersebut tetap bisa menikah dengan pertimbangan-pertimbangan tertentu. Termasuk kekhawatiran mereka akan terjerumus ke dalam pergaulan bebas.

Dalam situasi pandemi Covid-19 pernikahan yang dilakukan oleh pasangan di usia dini, menimbulkan berbagai kekhawatiran. Tidak hanya berhubungan dengan kemampuan ekonomi, yang pada faktanya secara umum mengalami guncangan, tapi juga mempertimbangkan kesehatan Ibu dan anakyang dikandung dan dilahirkan. Keadaan menjadi semakin mengkhawatirkan,jika pasangan yang menikah di usia dini tersebut segera memiliki anak setelah menikah. Sehingga untuk mengatasinya diperlukan semacam "kesepakatan menunda kehamilan" yang dituangkan dalam bentuk Perjanjian Perkawinan. Hal ini bertujuan untuk menghilangkan berbagai kekhawatiran dan berbagai hal buruk yang dapat mengancam eksitensi perkawinan. Kesepakatan tersebut tidak bertentangan dengan Hak Asasi Manusia (HAM) terutama yang berkaitan dengan kebebasan reproduksi. Karena perjanjian itu didasarkan atas kesepakatan bersama, dan bertujuan untuk melindungi kesehatan reproduksi. Lebih dari itu bertujuan melindungi dan memelihara anak yang dilahirkan, agar terhindar dari hal-hal yang tidak baik yang timbul dari konflik keluarga, karena tidak siap menghadapi berbagai problem yang relatif bertambah berat selama pandemi, di samping bertujuan melindungi anak tersebut dari ancaman virus yang berbaya dan mengancam kehidupannya.

Kesepakatan menunda kehamilan agar memiliki kekuatan hukum harus tuangkan dalam bentuk Perjanjian Perkawinan yang dibuat secara tertulis sebelum perkawinan. Meskipun tergolong ke dalam kategori syarat, jika sampai pada tahap harus dipenuhi oleh setiap pasangan yang akan melakukan pernikahan dini, namun syarat tersebut hanya bersifat administratif dan tidak berhubungan dengan keabsahan sebuah perkawinan. Apalagi jika kesepakatan tersebut hanya sebatas anjuran saja. Namun demikian pelanggaran atau ingkar janji (wanprestasi) terhadap isi Perjanjian Perkawinan, dapat menimbukan konsekuensi hukum berupa lahirnya hak dan kewajiban, sesuai dengan rincian perjanjian yang disepakati. Dengan demikian isi perjanjian tersebut akan mengikat pihak-pihak yang membuat kesepakatan dan menandatanganinya secara tertulis. Termasuk orang tua, sebagai pihak ketiga yang semestinya harus diikutsertakan, karena sudah mengajukan permohonan dispensasi agar dapat menikahkan anaknya yang masih berada di usia dini. 


\section{Daftar Pustaka}

Al-Ghazali. Al-Musthafa Min 'ilm Al-Ushul, Tahqiq Muhammad Sulayman Asyqar. Beirut: Al-Risalah, 1997.

Ali Jum'ah. Tarikh Ushul Al-Figh. Kairo: Dar al-Maqtham li al-Nasyr wa al-Tawzi', 2014.

Ali, St. Rahmah Syam. Dampak Covid 19 Terhadap Sosial Ekonomi Masyarakat Indonesia, Dalam Bunga Rampai Pandemi (Menyingkap Dampak Sosial Covid-19) Bunga Rampai Pandemi "Menyingkap Dampak -Dampak Sosial Kemasyarakatan Covid-19”. Parepare: IAIN Parepare Nusantara Press, 2020.

Amita Diananda. “Psikologi Remaja Dan Permasalahannya." Journal Istighna 1, no. 1 (2019): 116-33. Andi Mappiare. Psikologi Orang Dewasa, Usaha Nasional, n.d.

Angela. "Pengembangan Intimacy Pada Masa Dewasa Awal." binus.ac.id, 2015. https://psychology. binus.ac.id/2015/07/02/pengembangan-intimacy-pada-masa-dewasa-awal/.

Bernhard I. M. Supit. "Pembatalan Nikah Menurut Hukum Kanonik dalam Hubungannya dengan Sistem Perundang - Undangan di Indonesia." Lex Privatum 2, no. 1 (2015): 199-210. https:// ejournal.unsrat.ac.id/index.php/lexprivatum/article/view/7021.

Dani Somantri, Muhamad,DahwadinDahwadin, andFaisalFaisal. "Analisa Hukum Menunda Kehamilan Perkawinan Usia Dini Perspektif Istihsan Sebuah Upaya Membangun Keluarga Berkualitas." Mahkamah :Jurnal Kajian Hukum Islam 3, no. 2 (2018): 203. https://doi.org/10.24235/mahkamah. v3i2.3413.

Detik. “Gejala Global Pernikahan Dini Melonjak Di Masa Pandemi.” detik.com, 2020. https://news. detik.com/berita/d-5180276/gejala-global-pernikahan-dini-melonjak-di-masa-pandemi.

-_- "Menag: Angka Perceraian Meningkat Selama Covid-19." detik.com, 2020. https://news.detik. com/berita/d-5266413/menag-angka-perceraian-meningkat-selama-Covid-19.

E. B. Hurlock. Psikologi Perkembangan: Buatu Pendekatan Sepanjang Rentang Kehidupnn,Terj. Istiwidayanti Dan Soedjarwo. Jakarta: Erlangga, 1990.

Fauza, Nilna, and Moh Afandi. "Perjanjian Perkawinan Dalam Menjamin Hak-Hak Perempuan.” AlManhaj: Journal of Indonesian Islamic Family Law 2, no. 1 (2020): 1. https://doi.org/10.19105/almanhaj.v2i1.3116.

Indonesiabaik.id. "Posistif Hamil Di Tengah Corona Apa Risikonya." indonesiabaik.id, 2020. http:// indonesiabaik.id/infografis/positif-hamil-di-tengah-corona-apa-risikonya.

Jayani, Dwi Hadya. “Wabah Pernikahan Dini Di Tengah Pandemi Dan Dampak Buruknya." katadata. co.id, 2021. https://katadata.co.id/muhammadridhoi/analisisdata/5ff7cb5cdf279/wabahpernikahan-dini-di-tengah-pandemi-dan-dampak-buruknya.

Kasih, Ayunda Pininta. "Pakar Unpad: Angka Pernikahan Dini Melonjak Selama Pandemi." Kompas, 2020. https://edukasi.kompas.com/komentar/2020/07/08/131828971/pakar-unpad-angkapernikahan-dini-melonjak-selama-pandemi.

Kompas. "Perjalanan Pandemi Covid-19 Di Indonesia, Lebih Dari 100.000 Kasus Dalam 5 Bulan." kompas.com, 2020. https://www.kompas.com/tren/read/2020/07/28/060100865/perjalananpandemi-Covid-19-di-indonesia-lebih-dari-100.000-kasus-dalam-5?page=all.

--_. "WHO Tetapkan Wabah Virus Corona Sebagai Pandemi Global." kompas.com, 2020. https:// www.kompas.tv/article/70893/who-tetapkan-wabah-virus-corona-sebagai-pandemi-global. 
Marzuki, Peter Mahmud. Penelitian Hukum. Jakarta: Kencana, 2011.

Musthafa Dib al-Bugha, Muthafa al-Khin, 'Ali Sybarji. Al-Fiqh Al-Manhaji 'Ala Madzhab Al-Imam AlSyafi'I. Damaskus: Dar al-Musthafa, 2016.

News, BBC. “Anak Sekarang Terlalu Cepat Dewasa.” BBC NEWS Indonesia, 2013. https://www.bbc. com/indonesia/majalah/2013/03/130306_pendidikan_anak.

Orami, Majalah. "Moms, Ketahui Tanda Hingga Cara Mencegah Pubertas Dini Pada Anak." Orami, 2021. https://www.orami.co.id/magazine/pubertas-dini.

PKBI. “Hak Asasi Manusia (HAM) Dan Hak Kesehatan Reproduksi.” pkbi.or.id, 2015. https://pkbi. or.id/hak-asasi-manusia-ham-dan-hak-kesehatan-seksual-reproduksi-hksr/.

R.I, Direktorat Pembinaan Badan Peradilan Agama Islam Direktorat Jenderal Pembinaan Kelembagaan Agama Islam Departemen Agama. Kompilasi Hukum Islam, 2001.

RMOL. “Angka Kematian Ibu Hamil Meningkat Selama Pandemi Covid-19.” kesehatan.rmol.id, 2020. https://kesehatan.rmol.id/read/2020/11/24/462590/angka-kematian-ibu-hamil-meningkatselama-pandemi-Covid-19.

Satria Effendi M, Zein. Problematika Hukum Keluarga Islam Kontemporer, Analisis Yurisprudensi Dengan Pendekatan Ushuliyah. Jakarta: Kencana Prenada Group, 2015.

Somantri, Muhamad Dani, Dahwadin, Faisal. "Analisa Hukum Menunda Kehamilan Perkawinan Usia Dini Perspektif Istihsan Sebuah Upaya Membangun Keluarga Berkualitas.” Mahkamah: Jurnal Kajian Hukum Islam 3, no. 2 (2018): 212-13.

Suara.com. "Beban Berlipat Ganda Bagi Perempuan Di Masa Pandemi Covid-19." suara.com, 2020. https://www.suara.com/news/2020/04/19/124820/beban-berlipat-ganda-bagi-perempuandi-masa-pandemi-Covid-19? page $=5$.

Sumirat, Iin Ratna. "Pelanggaran Perjanjian Perkawinan Serta Akibat Hukumnya Analisis Hukum Positif Dan Hukum Islam.” Journal of Materials Processing Technology 1, no. 1 (2018): 1-8.

Syamsul Anwar. Metodologi Hukum Islam, n.d.

Undang-Undang No. 16 Tahun 2019 (n.d.).

Undang-Undang No. 23 Tahun 1992 Tentang Kesehatan (n.d.).

Undang-Undang No. 39 tahun 1999 tentang Hak Asasi Manusia (n.d.).

Undang-Undang Perkawinan No 1 Tahun 1974 Pasal 7 ayat (1) (n.d.). 